Kabul Tarihi: 10.01.2019

\title{
Destinasyona Yönelik Marka İmajı ve Marka Sadakati İlişkisinde Algılanan Destinasyon Kalitesinin Aracılık Rolü
}

\section{The Mediating Role of Perceived Destination Quality in the Relationship Between Brand Image and Brand Loyalty for Destination}

\author{
Dr. Öğr. Üyesi Cenk Murat KOÇOĞLU \\ Karabük Üniversitesi \\ Safranbolu Turizm Fakültesi \\ E-posta: cenk-murat@hotmail.com
}

\section{Öz}

$\mathrm{Bu}$ araştırma, destinasyon marka imajı ve destinasyon marka sadakati arasındaki ilişkide algılanan destinasyon kalitesinin aracılık rolünü ortaya koymak üzere gerçekleştirilmiştir. Araştırmada, veri toplama yöntemi olarak anket tekniğinden faydalanılmıştır. Araştırma evrenini Nevşehir destinasyonu ve bu destinasyona gelen yerli turistler oluşturmaktadır. Araştırma bulgularına göre, Nevşehir'e gelen yerli turistler, destinasyon marka imajı ve destinasyon marka sadakatini orta seviyede olumlu değerlendirirken algılanan destinasyon kalitesini nispeten daha az olumlu değerlendirmişlerdir. Araştırmanın hipotezlerine yönelik sonuçlara göre, destinasyon marka imajı ile destinasyon marka sadakati arasında pozitif bir ilişki tespit edilirken, bu ilişkide algılanan destinasyon kalitesinin kısmi aracılık rolü olduğu belirlenmiştir.

Anahtar Kelimeler: Destinasyon marka imajı, Algılanan destinasyon kalitesi, Destinasyon marka sadakati.

\begin{abstract}
This research was carried out to show the mediating role of perceived destination quality in the relationship between destination brand image and destination brand loyalty. In the research, questionnaire technique was benefited from as data gathering method. The population of the research constitutes Nevşehir destination and domestic tourists coming to this destination. According to the findings of the research, domestic tourists coming to Nevşehir evaluated the destination brand image and destination brand loyalty at a positive moderate level and they evaluated the quality of the perceived destination relatively less favorably. According to the results related hypothesis of the study, it was found that there was a positive relation between destination brand image and destination brand royalty and the perceived destination quality had a partial mediation role on the relationship.
\end{abstract}

Key Words: Destination brand image, Perceived destination quality, Destination brand loyalty. 


\section{Giriş}

Turizm talebinin oluşmasında ve destinasyonların pazarlanmasında, marka destinasyon olmanın önemi büyüktür. Bu nedenle birçok destinasyon sürekli artan turizm pazarından pay alabilmek için, yoğun şekilde markalaşma çabasına girişmektedir. Bu doğrultuda rekabet avantajı sağlamak isteyen destinasyonların marka olabilmesi, turistler üzerinde olumlu bir imaja sahip olmasıyla yakından ilişkilidir.

Destinasyon marka imajı, bir turistik destinasyonun farklı özelliklerinin, turistler tarafından ne şekilde algılandığıdır. Bu açıdan bakıldığında bir destinasyonun başka bir destinasyona tercih edilmesinde imaj oldukça etkili olmaktadır. Destinasyonların etkin bir şekilde pazarlanmasında, destinasyonların belirli aralıklarla imajının ölçülmesi ve bu imaj doğrultusunda bir pazarlama stratejisinin gerçekleştirilmesi gerekmektedir. Destinasyon marka imajının, destinasyonların marka değerinin belirlenmesinde en etkili değişken olduğu ifade edilmektedir (Konecnik ve Gartner, 2007). Destinasyon marka imajının, destinasyona ait algılanan kalite ve destinasyon marka sadakati ile ilişkili olduğu ve bu üç kavramın birlikte destinasyon pazarlanmasında güçlü etkileri olduğu literatürdeki bazı çalışmalarla (Chen ve Tsai, 2007; Choi ve diğ., 2011; Çetinsöz ve Karakeçili, 2018; Kock vd., 2016; Vinh ve Nga, 2015) desteklenmiştir. Bu yüzden birçok turistik destinasyon, diğer destinasyonlardan farklı konuma ulaşmak için, destinasyon marka imajını kullanmakta ve bu yolla destinasyonların kalitesini ve turistlerin destinasyona yönelik sadakat seviyelerini iyileştirmeyi hedeflemektedir (Camarero ve diğ., 2010: 496).

$\mathrm{Bu}$ çalışmanın amacı, Nevşehir destinasyonu özelinde, gelen turistlerin destinasyon marka imajı, algılanan destinasyon kalitesi ve destinasyon marka sadakati algılarını belirlemek ve bu üç kavramın birbirleri üzerindeki etkisini ve aracılık rolünü ortaya koymaktır. Konuyla ilgili araştırmalara bakıldığında genellikle destinasyonlara yönelik imaj ve marka değeri ile ilgili çalışmaların yapıldığı görülmektedir (Chi ve Qu, 2008; Konecnik ve Gartner, 2007; Teas ve Laczniak, 2004; Yüksel ve diğ., 2010). Bu araştırmanın söz konusu değişkenler arasındaki aracılık etkisini ortaya koyması açısından önemli olduğu düşünülmektedir. Araştırmada Nevşehir'e gelen 585 yerli turist üzerinde anket gerçekleştirilmiş ve elde edilen bulgular doğrultusunda hem literatüre hem de söz konusu destinasyonunun etkin pazarlanmasına yönelik katkılar ortaya konmaya çalışıımıştır.

\section{Kuramsal Çerçeve}

Bu bölümde destinasyon marka imajı, algılanan destinasyon kalitesi ve destinasyon marka sadakati kavramları ayrı ayrı incelenirken, aynı zamanda bu değişkenlerin birbirleri arasındaki ilişkiye değinilmiştir.

\subsection{Destinasyon Marka İmajı}

Bir bölgede turizmin gelişmesi açısından kritik öneme sahip olan destinasyon imajı (Taşçı ve Gartner, 2007), destinasyonda olması gerekli benzersiz özellikleri de içerisinde barındırmaktadır (Lertputtarak, 2012). Turizm pazarının gelişmesiyle birlikte turizm destinasyonları arasında rekabet daha da belirginleşmiş durumdadır (Ekinci ve Hosany, 2006). Bu yönüyle, bir destinasyonun rakip bir destinasyona tercih edilmesinde ve destinasyonların farklılaşmasında imaj oldukça etkili olmaktadır. Baloğlu ve McCleary'e (1999) göre, destinasyon imajı turistlerin destinasyon hakkındaki bilgi, inanç, his ve izlenimlerinin bütünüdür. Turizm destinasyonlarının belli 
bir imaja sahip olarak marka haline gelmesinde ve tercih edilen bir destinasyon olmalarında, turistik çekicilikler önem arz etmektedir (Kozak, 2010).

Öte yandan bu kavram, turistlerin davranışlarında, memnuniyetlerinde ve karar süreçlerinde de son derece etkilidir (Roig ve Clavé, 2016: 202). Destinasyon imajı turist çeken kaynakların akla gelmesini sağlayarak (Camarero ve diğ., 2010), turistlerin söz konusu destinasyonu ziyaret etmesinde ikna edici bir motivasyon oluşturmaktadır. Hunt'a (1975) göre, destinasyon imajı, bölgeyi tercih eden turist sayısının artırılmasında somut kaynaklardan daha etkili olmaktadır. Bu konuda yapılan çalışmalar (Baloğlu ve McCleary 1999; Bigne ve diğ., 2001; Lee ve diğ., 2005; Chen ve Tsai 2007; Choi ve diğ., 2011) destinasyon imajının, turistlerin tatil yeri seçim sürecinde ve bu tatil yerini tekrar ziyaret etme isteklerinde önemli etkiler oluşturduğunu göstermektedir. Nitekim Kock ve diğ. (2016) algılanan destinasyon imajına yönelik Almanya ve İspanya'da yaptıkları araştırmada, destinasyon imajının turistlerin tekrar ziyaret niyeti ve tavsiye davranışını pozitif etkilediğini tespit etmiştir. Benzer şekilde Phillips ve diğ. (2013), tarafından Amerika Birleşik Devletleri'nin Kuzey Dakota bölgesini ziyarete gelen yabancı turistler üzerinde yapılan bir çalışmada da aynı sonuçlar tespit edilmiştir.

\subsection{Algılanan Destinasyon Kalitesi}

Algılanan kalite, markanın statüsünü yükseltmede önemli etkiler sağlar (Aaker, 1996: 17). Pike ve diğ. (2010: 439) algılanan kaliteyi, bir mal ya da hizmetin rakip ürün ya da hizmete göre üstünlük algısı olarak açıklamaktadır. Kalite, gerçek ve algılanan kalite olarak ikiye ayrılmaktadır. Gerçek kalite, mal ya da hizmetlerin gereken şartlara uygun olma derecesi, algılanan kalite ise, tüketicinin beklediği performansın aldığı performansa göre üstünlügüdür (Towsend ve Gebhardt, 1998). Destinasyonlarda kalite ise, turistlerin herhangi bir destinasyondan aldıkları hizmet ile bekledikleri hizmet arasında yaptığı karşılaştırmadır (Chen, 2011: 85). Turistlerin destinasyon ile ilgili beklentilerin karşılanması ya da aşılması durumunda, algılanan destinasyon kalitesi yüksek olarak değerlendirilmektedir. Destinasyonların kalitesi de mal ya da hizmet gibi değerlendirilse de çok sayıda paydaşa ve işletmelere sahip olması ve dolayısıyla çok boyutlu değerlendirilme olanağı sebebiyle, destinasyonu oluşturan her bir arz unsurunun kontrol edilmesi çok zordur ve bu da destinasyonlarda algılanan kaliteyi etkilemektedir (Gartner ve Ruzzier, 2011: 474).

Destinasyon pazarlanmasında, algılanan destinasyon kalitesi, turizm araştırmacıları tarafından (Boo ve diğ., 2009; Konecnik ve Gartner 2007; Im ve diğ., 2012; Pike ve diğ., 2010) sıklıkla kullanılmaktadır. Algılanan kalitenin destinasyon markası ile ilgili değişkenlerin ölçülmesinde önemli bir boyut olduğu ifade edilmektedir. Destinasyon kalitesinin yüksek olduğu düşünülen durumlarda destinasyon markasının değerinin de yüksek olacağı değerlendirilmektedir (Teas ve Laczniak, 2004). Nitekim Deslandes (2003) tarafından yapılan bir araştırmada algılanan destinasyon kalitesi ile algılanan değer arasında pozitif yönlü bir ilişki tespit edilmiştir. Benzer şekilde bazı araştırmacılar da (Boo ve diğ., 2009; Cretu ve Brodie 2007; Marangoz, 2007; Netemeyer ve diğ., 2004; Ural ve Perk, 2012) yaptıkları araştırmalarda algılanan kalitenin marka sadakatini ve markaya yönelik satın alma niyetini pozitif bir şekilde etkilediğini ortaya koymuşlardır.

\subsection{Destinasyon Marka Sadakati}

Marka sadakati, tüketicilerin markaya karşı olumlu bir tutum sergilemesi ve gelecekte düzenli olarak bu markayı satın alma niyeti ve davranışıdır (Pappu ve diğ., 2005). 
Destinasyon sadakati ise, turistlerin devamlı olarak aynı destinasyonu ziyaret isteği ve bu destinasyonu başkalarına tavsiye etmesidir (Chen, 2011: 85). Destinasyon sadakati, sadece belirli bir döneme ait kısa dönemli bakış açısının yerine uzun dönemli bakış açısı gerektiren ve turistlerin yaşam boyu ziyaret davranışlarını dikkate almaktadır (Oppermann, 2000: 80). Diğer yandan turistlerin, ağızdan ağıza iletişim ve sosyal medya yoluyla viral olarak tatil deneyimlerini birbirleriyle paylaştıkları dikkate alındığında, birbirlerinin destinasyonlara yönelik sadakat seviyelerini etkileme gücüne sahip oldukları (Özoğul ve Özel, 2015: 140) ve davranışsal niyetlerini değiştirebilmektedirler.

Turizm literatüründe destinasyon sadakati, davranışsal ve tutumsal olarak iki şekilde ifade edilmektedir. Tutumsal destinasyon sadakati turistin bir çekim yerini diğer kişilere önermesi ve tekrar ziyaret etme niyeti olarak tanımlanırken (Myagmarsuren ve Chen, 2011; Pike ve Bianchi, 2013; Vinh ve Nga, 2015), davranışsal destinasyon sadakati turistin o destinasyona yönelik tatili tekrar satın almasıdır (Chi ve diğ., 2009). Destinasyon sadakati olan turistlerin, ilk defa o destinasyona gelen turistlere göre fiyat hassasiyetleri daha esnek olmaktadır (Petrick, 2004). Tayfun ve Yayla (2013) tarafından gerçekleştirilen bir araştırmada destinasyon sadakatini etkileyen en önemli faktörlerin; destinasyon imajı, ulaşımın kolaylığı, destinasyondaki işletmelerin nitelikli ve güvenilir olması, destinasyonda alternatif ürün çeşitliliği ve destinasyonun marka bilinirliği olduğu belirlenmiştir.

\subsection{Destinasyon İmajı ve Destinasyon Sadakati ve Algılanan Destinasyon Kalitesi Arasındaki İlişki}

Destinasyon imajının destinasyonu ziyaret eden kişilerin davranışlarını etkileme gücü vardır (Üner ve diğ., 2006: 192). Güçlü bir destinasyon imajı (Hallmann ve diğ., 2015), algılanan kaliteyi (Teas ve Laczniak, 2004) ve destinasyon marka sadakatini (Chi ve Qu, 2008; Choi ve diğ., 2011; Çetinsöz ve Artuğer, 2013; Dick ve Basu, 1994; Taşçı ve Gartner, 2007) olumlu bir şekilde etkilemektedir.

Konu ile ilgili daha önce yapılan çalışmalar (Milman ve Pizam, 1995; Bigne ve diğ., 2001) destinasyon imajı ve turistlerin destinasyonu tavsiye etme niyetleri arasında olumlu ilişki olduğunu ortaya koymaktadır. Destinasyon imajı ziyaretçi sadakatini ve tavsiye davranışını olumlu etkilerken (Chen ve Tsai, 2007: 1121) aynı zamanda turistlerin davranışsal niyetlerini de etkilemektedir (Chi ve Qu 2008). Illgili alanda yapılan araştırmalarda (Baker, 2007; Boo ve diğ., 2009; Chen ve Tsai, 2007; Choi ve diğ., 2011; Konecik ve Gartner 2007; İnan ve diğ., 2011; Pratminingsih ve diğ., 2014) destinasyon marka imajının, destinasyon marka sadakati üzerinde önemli etkileri olduğunu ortaya koymaktadır. Tüm bu araştırmalardan yola çıkarak şu hipotez geliş̧irilmiştir.

$\mathrm{H}_{1}$ : Destinasyon marka imajının destinasyon marka sadakati üzerinde olumlu etkisi vardır.

Destinasyon marka imajının aynı zamanda destinasyonun algılanan kalitesi üzerinde de etkileri olduğuna dair çalışmalar mevcuttur. Pike ve diğ., (2010) Avustralya turizm destinasyonu üzerine yaptıkları çalışmada, algılanan kalite ve marka imajı arasında pozitif bir ilişki olduğunu tespit etmişlerdir. Benzer olarak Atay ve Akyurt (2009), Uludağ destinasyonu üzerine yaptıkları araştırmada, Uludağ'ı ziyaret eden turistlerin Uludağ imajına ilişkin algılarının ziyaretçilerin kalite algıları üzerinde etkileri olduğunu ifade etmişlerdir. Aynı şekilde Çetinsöz ve Karakeçili'nin (2018) Anamur destinasyonun marka değerini belirlemeye yönelik yaptıkları araştırmada, destinasyon 
marka imajı ile destinasyonun algılanan kalitesi arasında olumlu ve güçlü bir korelasyon belirlemişlerdir. Bu araştırmalar bağlamında şu hipotez geliştirilmiştir.

$\mathrm{H}_{2}$ : Destinasyon marka imajının algılanan destinasyon kalitesi üzerinde olumlu etkisi vardır.

Algılanan destinasyon kalitesinin güçlü olduğu destinasyonlarda, destinasyon sadakatinin geliştiği ve turistlerin bu destinasyonu tekrar ziyaret etme ve başkalarına tavsiye etme eğiliminde oldukları literatürdeki bazı çalışmalarla desteklenmektedir (Gil ve diğ., 2007; Gül ve Bozok, 2015; Shabbir ve Rehman, 2013; Yapraklı ve Can, 2009) Nitekim, Vinh ve Nga (2015) tarafından yapılan çalışmada, algılanan destinasyon kalitesinin destinasyon marka sadakati üzerinde olumlu etkisi olduğu tespit edilmiştir.

Diğer yandan destinasyon marka imajının destinasyon markası boyutları içerinde en önemli boyut olduğu (Konecnik ve Gartner, 2007) ve destinasyon markalaşmasındaki birçok alt boyut ile ilişkisi olduğu ifade edilmektedir (Kim ve Kim, 2005). Bigne ve diğerlerinin (2000) yaptıkları çalışmada destinasyon imajı; algılanan kalite ve destinasyon sadakati arasında pozitif ilişkiler tespit edilmiştir. Benzer şekilde Çetinsöz ve Artuğer (2013) Antalya destinasyonun marka değerinin belirlenmesinde, destinasyon marka imajı, algılanan destinasyon kalitesi ve destinasyon marka sadakati arasında farklı derecede olumlu ilişkiler olduğunu tespit etmişlerdir. Aynı şekilde, Yağmur ve Kolukısa (2016) Fransız turistlerin Kemer destinasyonuna ait marka değerini belirledikleri araştırmada, destinasyon marka imajının hem algılanan destinasyon kalitesi ve hem de destinasyon marka sadakatini etkilediğini, algılanan destinasyon kalitesinin de destinasyon marka sadakatini etkilediğini tespit etmişlerdir. Ayrıca, destinasyon marka imajı ile algılanan destinasyon kalitesinin diğer boyutlardan çok daha güçlü ve olumlu ilişkiye sahip oldukları ifade edilmiştir. Tüm bu araştırmalardan yola çıkılarak, şu hipotezler geliştirilmiştir.

$\mathrm{H}_{3}$ : Algılanan destinasyon kalitesinin destinasyon marka sadakati üzerinde olumlu etkisi vardır.

$\mathrm{H}_{4}$ : Destinasyon marka imajı ile destinasyon marka sadakati ilişkisinde algılanan destinasyon kalitesinin aracılık etkisi vardır.

\section{Yöntem}

Destinasyon marka imajı ve destinasyon marka sadakati ilişkisinde algılanan destinasyon kalitesinin aracılık rolünü belirlemek üzere gerçekleştirilen bu çalışmada sayısal verilere dayalı olan nicel araştırma yöntemi kullanılmış ve veri toplamada anket tekniğinden faydalanılmıştır.

\subsection{Veri Toplama Aracının Hazırlanması}

Soru formunun hazırlanmasında konuyla ilgili literatürdeki çalışmalardan yararlanılmıştır (Boo ve diğ., 2009; Konecnik ve Gartner, 2007; Pike ve diğ., 2010). Çalışma kapsamında soru formunda 5'li Likert tipi ölçek kullanılmıştır. Soru formunun kapsam geçerliliğinin saptanması için konuya hakim akademisyenler ile görüşülmüş ve bu doğrultuda sorularda anlam güçlüğü oluşturabilecek ifadeler düzeltilmiştir. Anket uygulamasından önce, anketin içeriğinde yer alan değişkenler ve kullanılan ölçekle ilgili karşılaşılabilecek muhtemel sorunları önceden görebilmek için (Yüksel ve Yüksel, 2004) 40 yerli turiste bir pilot uygulama gerçekleştirilerek soru formuna son şekli verilmiştir. 


\subsection{Evren ve Örneklem}

Araştırma evrenini Nevşehir'e gelen yerli turistler oluşturmaktadır. Nevşehir doğal ve kültürel değerleriyle dikkat çeken ve yoğun ziyaretçi akınına uğrayan turistik destinasyonlar arasında yer almaktadır. TÜIK verilerine göre 2017 yılının ikinci çeyreğinde Nevşehir' e gelen toplam turist sayısının bir önceki yıla göre $\% 48$ oranında artış gösterdiği belirtilmektedir. Ayrıca söz konusu destinasyonda mevcut araştırmaya benzer bir araştırmanın gerçekleştirilmemiş olması da Nevşehir'in araştırma evreni olarak seçilmesinde etkili olmuştur. Anketler, 2017 Şubat ve Nisan aylarında Nevşehir'e ait önemli ziyaret noktalarında ve turistlerin konakladıkları otellerde uygulanmıştır. Araştırmada örnekleme yöntemi olarak tesadüfi olmayan örnekleme yöntemlerinden kolayda örnekleme yöntemi kullanılmış ve Nevşehir'de minimum 2 gün geçirmiş olma şartını sağlayan turistler araştırmaya dahil edilmiştir. Yüksel ve Yüksel'e (2004) göre, örneklemi etkileyen birçok değişken olmasından dolayı örneklemin hesaplanmasından çok araştırmacının uygun veriyi elde edebileceği büyüklüğe ulaşması gerekmektedir. Bu nedenle, Sekaran'ın (2003) araştırma evrenindeki bireylerin sayısının bir milyon ve üzeri olması durumunda 0.95 güvenilirlikle 384 örneklem büyüklüğünün yeterli olacağı görüşü dikkate alınmış ve 585 katılımcı örnek sayısını oluşturmuştur.

\subsection{Araştırmanın Modeli}

Destinasyon marka imajı ve destinasyon marka sadakati ilişkisinde algılanan destinasyon kalitesinin aracı rolünün belirlenmesinde Baron ve Kenny (1986) tarafından önerilen analizi yöntemi kullanılmıştır. Buna göre destinasyon marka imajı ile destinasyon marka sadakati arasında doğrudan etki (c), destinasyon marka imajı ile algılanan destinasyon kalitesi arasındaki etki (a) ve algılanan destinasyon kalitesi ile destinasyon marka sadakati arasındaki aracı etki (b) bulunmaktadır.

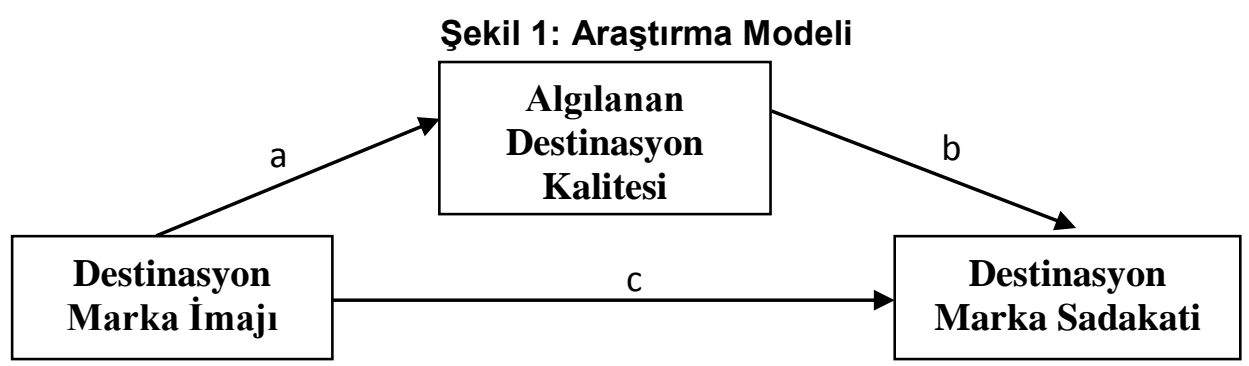

Eğer destinasyon marka imajı ve destinasyon marka sadakati arasındaki doğrudan ilişki anlamlıyken, algılanan destinasyon kalitesi ile bu ilişki anlamlılığını kaybediyorsa tam bir aracılık etkisi bulunmaktadır. Eğer algılanan destinasyon kalitesi aracı değişkeni modele eklendikten sonra destinasyon marka imajı ile destinasyon marka sadakati arasındaki doğrudan ilişki anlamlılığını koruyor fakat c katsayısı azalıyorsa, burada kısmi aracı etki ortaya çıkmaktadır (Baron ve Kenny, 1986)

\section{Bulgular}

Araştırmaya katılan kişilerle ilgili bazı tanıtıcı bilgileri ortaya koymak için yapılan frekans analizi sonuçlarına göre, katılımcıların \%58'i erkek, \%42'si kadınlardan oluşmaktadır. Katılımcıların yaşları incelendiğinde yaklaşık yarısının 25-44 yaş aralığında, büyük bir çoğunluğunun evli olduğu ve yaklaşık yarısının üniversite eğitimi aldığı dikkat çekmektedir. Diğer yandan katılımcıların Nevşehir'i daha önce ziyaret 
etme durumlarına bakıldığında, büyük bir çoğunluğunun (\%78) en az iki ve daha çok kez, söz konusu destinasyonu ziyaret ettiği ortaya çıkmıştır.

\subsection{Değişkenlere Yönelik Açıklayıcı Faktör Analizi}

Destinasyon marka imajı, algılanan destinasyon kalitesi ve destinasyon marka sadakati değişkenlerinin boyutsal yapılarını ortaya çıkarmak, güvenilirlik ve geçerliliğini belirlemek amacıyla açıklayıcı faktör analizi gerçekleştirilmiştir. Öncelikle değişkenlere güvenilirlik analizi yapılmış ve Cronbach Alfa katsayısının ",860" olduğu ortaya konmuştur. Nunnaly ve Bernstein'a (1994) göre, bu değer, ölçeğin güvenilir ve geçerli kabul edilebilmesi için gerekli olan 0,70 'in üzerindedir.

Tablo 1: Değişkenlere Yönelik Faktör Analizi ve Ortalamalar

\begin{tabular}{|c|c|c|c|}
\hline Kurumsal İtibar Algısı Boyutları & $\begin{array}{l}\text { Faktör } \\
\text { Yükleri }\end{array}$ & $\begin{array}{l}\text { Varyans } \\
\%\end{array}$ & C. Alfa \\
\hline \multicolumn{2}{|l|}{ Destinasyon Marka İmajı x: 3,87} & \multirow{5}{*}{26,90} & \multirow{5}{*}{,889 } \\
\hline Nevşehir, doğal güzelliklere sahip bir şehirdir. & ,868 & & \\
\hline Nevşehir, tarihi çekicilikler sunmaktadır. & ,848 & & \\
\hline Nevşehir, bir kültür şehridir. & ,837 & & \\
\hline Nevşehir, huzur veren bir atmosfere sahiptir. & ,831 & & \\
\hline Nevşehir, heyecan verici bir atmosfere sahiptir. & ,698 & & \\
\hline \multicolumn{2}{|l|}{ Destinasyon Marka Sadakati $\bar{x}: 3,39$} & \multirow{4}{*}{21,68} & \multirow{4}{*}{,818 } \\
\hline Nevşehir’i gelecekte de ziyaret edeceğim. & ,826 & & \\
\hline Kendimi Nevşehir'e bağlı bir turist olarak görüyorum. & ,792 & & \\
\hline Nevşehir tatil yapmak için ilk tercih edeceğim bir şehirdir. & ,784 & & \\
\hline Nevşehir'i çevremdeki insanlara tavsiye ederim. & ,777 & & \\
\hline \multicolumn{2}{|l|}{ Algılanan Destinasyon Kalitesi $\overline{\mathbf{x}}: \mathbf{3 , 0 8}$} & \multirow{4}{*}{20,20} & \multirow{4}{*}{,848 } \\
\hline Nevşehir yüksek kalitede konaklama olanaklarına sahiptir & ,785 & & \\
\hline Nevşehir yüksek kalitede altyapıya sahiptir & ,783 & & \\
\hline Nevşehir çok temiz bir yerdir. & ,780 & & \\
\hline Nevşehir güvenli bir yerdir. & ,772 & & \\
\hline \multicolumn{4}{|c|}{$\begin{array}{l}\text { Cronbach Alfa: } 0,860 \quad \text { Toplam Varyans: } 68,76 . \quad \text { Çıkarım Yöntemi: Temel Bileşenler Analizi, } \\
\text { Döndürme Yöntemi: Kaiser Normalleştirmesi ve Varimax, İterasyon Sayısı: } 5 \\
\text { KMO Uygunluk Ölçütü: } 0,863 \text {. Barlett Küresellik Testi x2: } 3766,611 \quad \text { p: } 0,000\end{array}$} \\
\hline
\end{tabular}

Kaiser Normalleştirmesinde, özdeğeri 1'den büyük faktörler dikkate alınmış ve ölçeğin 3 faktörden oluştuğu belirlenmiştir. Araştırmanın varyans yüzdesi toplamı 68,76 çıkmıştır. Bu oran \%50'den yüksek olduğu için analizin geçerli olduğunu göstermektedir (Scherer, Luther, Wiebe, 1988). Açıklayıcı faktör analizinde ortak varyans (communality) değerleri ile ölçekteki maddelerin değerlerinin 0,4'ten düşük olmaması gerekmektedir (Field, 2000: 434). Yapılan bu faktör analizinde de tüm değerler 0,4'ten büyük olarak gerçekleşmiştir. Açıklayıcı faktör analizi sonucunda, birinci faktör (5 madde) destinasyon marka imajı, ikinci faktör (4 madde) destinasyon marka sadakati ve üçüncü faktör (4 madde) algılanan destinasyon kalitesine yönelik ifadeleri içermektedir. Bu faktörlerin Cronbach's Alfa değerlerine bakıldığında destinasyon marka imajının 0,89 , destinasyon marka sadakatinin 0,82 ve algılanan destinasyon kalitesinin ise 0,85 değerlerinde olduğu görülmektedir. Nunnally (1978) 0,70 ve üzeri Cronbach katsayısının iyi düzeyde içsel güvenirliğe işaret ettiğini belirtmektedir.

Değişkenlere yönelik ortalamalara bakıldığında, destinasyon marka imajının $(\bar{x}=3,87)$ en yüksek ortalamaya sahip olduğu, bunu sırasıyla destinasyon marka sadakati $(\bar{x}=3,39)$ ve algılanan destinasyon kalitesi $(\bar{x}=3,08)$ değişkenlerinin izlediği görülmektedir. 
Diğer yandan korelasyon analizine geçmeden önce, verilerin normal dağılıp dağılmadığı, çarpıklık ve basıklık değerleri ile kontrol edilmiş ve çarpıklık ve basıklık değerleri -1.5 ile +1.5 arasında olduğundan dolayı (Tabachnick ve Fidell, 2013), normal dağıldığı belirlenmiştir. Buna göre Pearson Korelasyon testi gerçekleştirilmiştir.

Tablo 2: Değişkenler Arasındaki Korelasyon Analizi

\begin{tabular}{|l|l|l|l|}
\hline Boyutlar & DMI & ADK & DMS \\
\hline Destinasyon Marka İmajı & 1 &, $234^{* *}$ &, $321^{* *}$ \\
\hline Algılanan Destinasyon Kalitesi & & 1 &, $440^{* *}$ \\
\hline “** $\mathrm{p}<0.01 "$
\end{tabular}

Değişkenler arasındaki ilişkiyi tespit etmek için yapılan Pearson korelasyon testi Tablo 2'de yer almaktadır. Buna göre, değişkenler arasındaki korelasyon katsayılarının tamamı pozitif ve anlamlı bulunmuştur $(p<0,01)$. Pearson Korelasyon kat sayılarına bakıldığında, destinasyon marka imajı ve algılanan destinasyon kalitesi arasında pozitif yönde zayıf seviyede bir ilişki belirlenmiştir $(r=0,234 ; p<0,01)$. Bununla birlikte, destinasyon marka imajı ile destinasyon marka sadakati arasında $(r=0,321 ; p<0,01)$ pozitif yönde zayıf derecede ilişki tespit edilmiştir. Diğer yandan, algılanan destinasyon kalitesi ve destinasyon marka sadakati arasında $(r=0,440 ; p<0,01)$ pozitif ve orta seviyede bir ilişki bulunmuştur.

\subsection{Hipotezlerin Testi}

Tablo 3'te verilen modelin test edilebilmesi için yukarıda geliştirilen $H_{1}, H_{2}, H_{3}$ ve $H_{4}$ hipotezleri için regresyon analizi gerçekleştirilmiştir.

Tablo 3: Değişkenler Arasındaki Regresyon Analizine İlişkin Modeller

\begin{tabular}{|l|l|l|l|}
\hline Model 1 (Bağımlı Değişken: Destinasyon Marka Sadakati) \\
\hline Bağımsız Değişken & Beta & $\mathbf{t}$ & $\mathbf{P}$ \\
\hline Destinasyon Marka İmajı &, 321 & 8,172 &, 000 \\
\hline $\mathrm{R}=, 321 ; \mathrm{R}^{2}=, 103 ;$ Düzeltilmiş $\mathrm{R}^{2}=, 101 ; \quad \mathrm{F}=50,862 ; \quad \mathrm{p}=0.000$ \\
\hline Model 2 (Bağımlı Değişken: Algılanan Destinasyon Kalitesi) \\
\hline Bağımsız Değişken & Beta & $\mathbf{t}$ & $\mathbf{P}$ \\
\hline Destinasyon Marka İmajı &, 234 & 5,803 &, 000 \\
\hline $\mathrm{R}=, 234 ; \mathrm{R}^{2}=, 055 ;$ Düzeltilmiş $\mathrm{R}^{2}=, 053 ; \mathrm{F}=33,677 ; \quad \mathrm{p}=0.000$ \\
\hline Model 3 (Bağımlı Değişken: Destinasyon Marka Sadakati) \\
\hline Bağımsız Değişkenler & Beta & $\mathbf{t}$ \\
\hline Destinasyon Marka İmajı & $\mathbf{P}$ \\
\hline Algılanan Destinasyon Kalitesi &, 230 &, 000 \\
\hline $\begin{array}{l}\mathrm{R}=, 494 ; \quad \mathrm{R}^{2}=, 244 ; \text { Düzeltilmiş } \mathrm{R}^{2}=, 241 ; \quad \mathrm{F}=93,624 ; \quad \mathrm{p}=0.000 \\
\text { Tolerans=0,850; VIF=1, } 177\end{array}$ &, 000 \\
\hline
\end{tabular}

Algılanan destinasyon kalitesinin aracılık etkisini test etmek için Baron ve Kenny'nin (1986) aracılık etkisi modelinden faydalanılmıştır. Bu amaçla hiyerarşik regresyon analizi yapılmıştır. Aracılık hipotezinin kabul edilmesi için, bağımsız değişken (destinasyon marka imajı), bağımlı değişken (destinasyon marka sadakati) ile olduğu gibi aracı değişken (algılanan destinasyon kalitesi) ile de ilişkili olmalıdır. Aracılık etkisinin testinde üç regresyon modeli gerekmektedir. Tablo 3 'te algılanan destinasyon kalitesinin aracılık etkisini test eden regresyon analizi yer almaktadır.

Model 1, destinasyon marka imajının destinasyon marka sadakati üzerinde pozitif ve anlamlı bir etkisinin olduğu yönündedir $(\beta=0,321 ; p=0,000)$. Buna göre $H_{1}$ hipotezi kabul edilmiştir. Model 2'de destinasyon marka imajının algılanan destinasyon kalitesi 
üzerindeki pozitif ve anlamlı etkisi görülmektedir $(\beta=0,234 ; p=0,000)$. Bu durumda $\mathrm{H}_{2}$ hipotezi de kabul edilmiştir. Model 3'de destinasyon marka imajı değişkenine algılanan destinasyon kalitesi eklendiğinde algılanan destinasyon kalitesinin, destinasyon marka sadakati üzerinde pozitif ve anlamlı bir etkisinin olduğu $(\beta=0,386 ; p=0,000)$ ve destinasyon marka imajının, Model 1'deki $\beta=0,321$ olan katsayısı, Model 3'te $\beta=0,230$ 'a düşerek, anlamlı etki devam etmiştir. Bu doğrultuda kısmi aracılık etkisinden söz edilmektedir. Bu sonuçlara göre, destinasyon marka imajı ile destinasyon marka sadakati arasındaki ilişkide, algılanan destinasyon kalitesinin 0,01 anlamlılık düzeyinde bir kısmi bir aracılık etkisinin olduğu belirlenmiştir. Ancak kesin olarak aracı etkiden söz etmek için, beta değerlerindeki azalmanın anlamlılığı Sobel Testi ile analiz edilmiştir. Sobel testi sonuçları da, destinasyon marka imajı ile destinasyon marka sadakati arasındaki ilişkide algılanan destinasyon kalitesinin aracılık etkisinin olduğunu desteklemektedir $(Z=6,156 p=0,000)$. Buna göre $H_{3}$ hipotezi kabul edilirken, $H_{4}$ hipotezi kısmen kabul edilmiştir.

Ayrıca üçüncü modelde iki farklı değişken, bağımsız değişken olarak modele dahil edildiği için çoklu bağıntı ve oto-korelasyon (multicollinearity) olup olmadığı test edilmiştir. VIF=1,177 ve Tolerans $=0,850$ değerleri, değişkenler arasında çoklu bağıntı ve oto-korelasyon olmadığını göstermektedir (Field, 2000).

\section{Sonuç ve Öneriler}

$\mathrm{Bu}$ araştırmada destinasyon marka imajı ile destinasyon marka sadakati arasındaki ilişkide, algılanan destinasyon kalitesinin aracılık etkisi ortaya konmaya çalışılmıştır. Araştırma modeline göre, destinasyon marka imajı, algılanan destinasyon kalitesi ve destinasyon marka sadakati arasında pozitif yönde ilişkinin olduğu kabul edilmektedir.

Analiz sonuçlarına bakıldığında; destinasyon marka imajının $(\bar{x}=3,87)$ en yüksek ortalamaya sahip olduğu, bunu sırasıyla destinasyon marka sadakati $(\bar{x}=3,39)$ ve algılanan destinasyon kalitesi $(\bar{x}=3,08)$ değişkenlerinin takip ettiği belirlenmiştir. Buna göre Nevşehir destinasyonun turistler tarafından olumlu bir imaja sahip olduğu bu destinasyona gelen turistlerin tekrar gelme isteği duyduğu fakat algılanan destinasyon kalitesi noktasında diğer değişkenlere göre iyi algılanmadığı da değerlendirilmektedir. Diğer yandan araştırmanın değişkenleri arasındaki korelasyon analizi sonuçlarına göre; algılanan destinasyon kalitesi arasında pozitif ilişki, destinasyon marka imajı ile destinasyon marka sadakati arasında pozitif ilişki ve algılanan destinasyon kalitesi ile destinasyon marka sadakati arasında pozitif ilişkiler ortaya çıkmıştır. Değişkenler arasındaki ilişkinin seviyesine bakıldığında, algılanan destinasyon kalitesi ve destinasyon marka sadakati arasında çok daha güçlü pozitif ilişki olduğu belirlenmiştir. Nitekim bu konuda yapılan araştırmalar bu araştırmayı destekler niteliktedir (Baloğlu ve McCleary 1999; Bigne ve diğ., 2001; Chen ve Tsai 2007; Choi ve diğ., 2011; Lee ve diğ., 2005).

Araştırmanın hipotezlerine yönelik sonuçlara bakıldığında; Baron ve Kenny (1986) tarafından ortaya konan aracılık modeli kapsamında, üç ayrı regresyon modeli uygulanmıştır. Buna göre destinasyon marka imajının destinasyon marka sadakati üzerinde; destinasyon marka imajının algılanan destinasyon kalitesi üzerinde pozitif ve anlamlı etkilerinin olduğu tespit edilmiştir. Modele destinasyon marka imajı ve algılanan destinasyon kalitesi eklendiğinde, bu iki değişkenin destinasyon marka sadakati üzerindeki etkilerine bakıldığında, algılanan destinasyon kalitesinin, destinasyon marka sadakati üzerinde pozitif ve anlamlı etkisinin olduğu ve destinasyon marka imajı ile destinasyon marka sadakati arasında, algılanan destinasyon kalitesinin kısmi bir aracı etkisinin olduğu ortaya çıkmıştır. Bigne ve diğ., (2000) ile Gartner ve Ruzzier (2011) ve 
Ferns ve Walls (2012) tarafından yapılan araştırmalarda da destinasyon imajı; algılanan kalite ve destinasyon sadakati arasında pozitif ilişkiler tespit edilmiştir. Benzer şekilde Çetinsöz ve Artuğer (2013) Antalya destinasyonun marka değerinin belirlenmesinde, destinasyon marka imajı, algılanan destinasyon kalitesi ve destinasyon marka sadakati arasında farklı derecede olumlu ilişkiler olduğunu tespit etmişlerdir. Aynı şekilde, Yağmur ve Kolukısa (2016) tarafından Fransız turistlerin Kemer destinasyonuna ait marka değerinin belirlendiği araştırmada da benzer sonuçlar bulunmuştur.

Destinasyonların etkin bir şekilde pazarlanmasında, destinasyon marka imajının, algılanan destinasyon kalitesinin ve destinasyon marka sadakatinin önemi büyüktür. Araştırmada ortaya çıkan sonuçlar, destinasyon marka imajının hem doğrudan hem de algılanan destinasyon kalitesinin aracı rolü ile destinasyon marka sadakatini olumlu olarak etkilediği yönündedir. Dolayısıyla bu değişsenlerin birinde sağlanan olumlu gelişme, diğer değişkenlerde de olumlu gelişmeler ortaya çıkaracaktır.

Araştırmada elde edilen bulgular ve sonuç doğrultusunda şu önerilerde bulunulabilir. Öncelikle Nevşehir önemli kültürel destinasyonlardan biridir. Destinasyonun gelişmesinde önemli unsurların başında, destinasyon marka imajı, destinasyon marka sadakati ve algılanan destinasyon kalitesi gelmektedir. Bu değişkenlerde yapılan iyileştirmeler, destinasyonu diğer destinasyonlar karşısında rekabette öne çıkaracaktır. Nevşehir destinasyonun marka imajı ve marka sadakati, gelen turistler tarafından orta seviyede olumlu algılanırken, algılanan destinasyon kalitesi görece düşük derecede olumlu algılanmıştır. Bu doğrultuda; özellikle algılanan destinasyon kalitesi anlamında turistlerin beklentilerini bilmek ve bu beklentileri karşılayacak faaliyetler yürütmek gerekmektedir. Turistlerin algılanan kalitesini artıracak, alt yapı ve üst yapıda iyileştirmeler ve bölgede faaliyetler gösteren konaklama ve diğer turistik işletmelerinin hizmet kalitesini yükseltmek gerekmektedir. Bununla birlikte kaliteli hizmet algısı oluşturabilecek insan kaynaklarına da aynı özen gösterilmelidir. Nitekim kalite turistin talep ettiği ürünü onu tatmin edecek şekilde sunabilmeyi gerektirmektedir. Diğer yandan, destinasyon marka imajının algılanan destinasyon kalitesi ve destinasyon marka sadakati üzerinde olumlu etkisinden hareketle, özellikle destinasyon marka imajını diğer kültürel destinasyonlardan farklılaştıran pazarlama faaliyetlerinin yürütülmesi hem algılanan destinasyon kalitesinde hem de destinasyon marka sadakati üzerinde olumlu etkiler oluşturabilecektir.

Bu çalışma Nevşehir destinasyonu özelinde, destinasyon marka imajı, algılanan destinasyon kalitesi ve destinasyon marka imajı arasındaki etkileşime odaklanmaktadır. Bu kapsamda araştırma Nevşehir destinasyonu ve yerli turistlerin değerlendirmesiyle sınılıdır. Gelecekte farklı destinasyonlar ve farklı örneklem grupları üzerinde yapılacak araştırmaların konunun daha geniş bir bakış açısıyla değerlendirilmesine imkan vereceği düşünülmektedir.

\section{Kaynakça}

Aaker, D.A. (1996), Building Strong Brands, New York: The Free Press.

Atay, L. ve Akyurt, H. (2009), "Uludağ Destinasyonunun İmajına Yönelik Ziyaretçi Algı ve Tutumlarını Belirlemeye Yönelik Bir Araştırma”, Seyahat ve Otel İşletmeciliği Dergisi, 6 (3).

Baloğlu, Ş. ve McCleary, K. W. (1999), "A model of Destination Image Formation", Annals of Tourism Research, 26 (4), ss. 868-897. 
Baron, R. M. ve Kenny, D. A. (1986), "The Moderator-Mediator Variable Distinctionin Social Psychological Research: Conceptual, Strategic, and Statistical Considerations", Journal of Personality and Social Psychology, 51 (6), ss. 11731182.

Bigne, J. E., Sanchez, M. I. ve Sanchez, J. (2001), "Tourism Image, Evaluation Variables and After Purchase Behavior: Interrelationship", Tourism Management, 22 (6), ss. 607-616.

Boo, S., Busser, J. ve Baloglu, S. (2009), "A Model of Customer-Based Brand Equity and Its Application to Multiple Destinations", Tourism Management, 30 (2), ss. 219-231.

Camarero, Carmen, Garrido, María José ve Vicente, Eva (2010), Components of Art Exhibition Brand Quity for Internal and External Visitors, Tourism Management, 31, ss. 495-504.

Chaudhuri, A. ve Morris, H. B. (2001), "The Chain of Effects from Brand Trust and Brand Affect to Brand Performance: The Role of Brand Loyalty", Journal of Market, 65 (2), 81-93.

Chen, C. F. (2011), "Exploring Relationships Between Destination Brand Equity, Satisfaction and Destination Loyalty: A Case Study of Mongolia", Journal of Tourism, Hospitality \& Culinary Arts, 3 (2), ss. 81-94.

Chen, F.C. ve Tsai, D. C. (2007), "How Destination Image and Evaluative Factors Affect Behavioral Intentions?", Tourism Management,28 (1), ss. 1115-1122.

Chi, G. C. ve Qu, H. (2008), "Examining The Structural Relationships of Destination Image, Tourist Satisfaction and Destination Loyalty: An Integrated Approach", Tourism Management, 29 (4), ss. 624-636.

Chi, H., K., Yeh, H., R. ve Yang, Y.T. (2009), "The Impact of Brand Awareness On Consumer Purchase Intention: The Mediating Effect of Perceived Quality and Brand Loyalty", The Journal of International Management Studies, 4 (1), ss. 135144.

Choi, G. J., Tkachenko, T. ve Sil, S. (2011), "On The Destination Image of Korea By Russian Tourists", Tourism Management, 32, ss. 193-194.

Cretu, A. E., ve Brodie, R. J. (2007), "The Influence of Brand Image and Company Reputation Where Manufacturers Market to Small Firms: A Customer Value Perspective", Industrial Marketing Management, 36 (2), ss. 230-240.

Çetinsöz, B.C. ve Artuğer, S. (2013), "Antalya İlinin Marka Değerinin Ölçülmesine Yönelik Bir Araştırma”, Anatolia: Turizm Araştırmaları Dergisi 24 (2), ss. 200210.

Deslandes, D. D. (2003), Assessing Consumer Perceptions of Destinations: A Necessary First Step in The Destination Branding Process. (Yayımlanmamış Doktora Tezi).The Florida State Üniversitesi.

Dick, A. S. ve Basu, K. (1994), "Customer Loyalty: Toward an Integrated Conceptual Framework", Journal of the Academy of Marketing Science. 22 (2), ss. 99-113.

Ekinci, Y. ve Hosany, S. (2006), "Destination Personality: An Application of Brand Personality to Tourism Destinations", Journal of Travel Research, 45, ss. 127139.

Ferns, B. H. ve Walls, A. (2012), "Enduring Travel Involvement, Destination Brand Equity and Travelers' Visit Intentions: a Structural Model Analysis", Journal of Destination Marketing \& Management, 1, ss. 27-35.

Field, A. (2000), Discovering Statistics-Using SPSS for Windows, Sage Pub. London.

Gartner, W. C. ve Ruzzıer, M. (2011), "Tourism Destination Brand Equity Dimensions: Renewal Versus Repeat Market". Journal of Travel Research, 50 (5), ss. 471481. 
Gil, R. B., Andres, E.F. ve Salinas, E.M., (2007), "Family As A Source Of ConsumerBased Brand Equity", The Journal of Product and Brand Management, 16 (3), Ss. 188-199.

Gül, M. ve Bozok, D. (2015), “Müşteri Temelli Marka Değerinin Yaratılması ve Termal Turizm Amaçlı Seyahat Eden Turistlerin Marka Algılarının Ölçülmesi: Balçova Termal Tesislerine Yönelik Bir Araştırma", İşletme Araştırmaları Dergisi, 7 (3), ss. 432-456.

Hallmann, K., Zehrer, A. ve Müller, S. (2015), "Perceived Destination Image: An Image Model for a Winter Sports Destination and Its Effect on Intention to Revisit", Journal of Travel Research, 54 (1), ss. 94-106.

Hunt, J.D. (1975), "Image as a factor in tourism development", Journal of Travel Research, Winter, ss. 1-7.

Im, H.H., Kim, S.S., Elliot, S. ve Han, H. (2012), "Conceptualizing Destination Brand Equity Dimensions from a Consumer-Based Brand Equity Perspective", Journal of Travel \& Tourism Marketing, 29, ss. 385-403.

İnan, E. A.; Akıncı, S.; Kıymalıoğlu, A. ve Akyürek, M. S. (2011), "Kruvaziyer Turizminde Turistlerin Tavsiye Niyetlerinde Destinasyon İmajının Etkisi", Ege Akademik Bakış, 11 (3), ss. 487-497.

Kim, H. B. ve Kim, W. G. (2005), "The Relationship Between Brand Equity and Firms, Performance in Luxury Hotels and Chain Restaurant", Tourism Management, 26: ss. 549-560.

Kock, F., Josiassen, A., ve Assaf, G. A. (2016), "Advancing Destination Image: The Destination Content Model", Annals of Tourism Research , 61, ss. 28-44

Konecnik, M. ve Gartner, W. C. (2007), "Customer Based Brand Equity for A Destination", Annals of Tourism Research, 34 (2), ss. 400-421.

Kozak, N. (2010), Turizm Pazarlaması (3. Baskı), Ankara: Detay Yayıncılık

Lee C., Lee, Y. ve Lee, B. (2005), "Korea's Destination Image Formed By The 2002 World Cup", Annals of Tourism Research, 32 (4), ss. 839-858.

Lertputtarak, S. (2012), "The Relationship Between Destination İmage, Food İmage, And Revisiting Pattaya, Thailand", International Journal of Business and Management, 7 (5), ss. 111-121.

Marangoz, M. (2007), "Tüketici Davranışı Temeline Göre Marka Değerinin Ölçülmesine Yönelik Bir Araştırma, Öneri Dergisi, 7 (28): 87-96.

Marine-Roig, E. ve Clavé, S. (2016), "Perceived İmage Specialisation İn Multiscalar Tourism Destinations", J. Destin. Mark. Manag, 5, ss. 202-213.

Milman, A. ve Pizam, A. (1995), "The Role Of Awareness And Familiarity With A Destination: The Central Florida Case", Journal of Travel Research, 33 (3), ss. 21-27.

Myagmarsuren, O. ve Chen, C. (2011), "Exploring Relationships Between Destination Brand Equity, Satisfaction, and Destination Loyalty: a Case Study of Mongolia", Journal of Tourism, Hospitality \& Culinary Arts, 3 (2), ss. 81-94.

Netemeyer, R. G., Krishnan, B., Pullig, C., Wang, G., Yagci, M., Dean, D., Ricks, J., ve Wirth, F. (2004), "Developing and Validating Measures of Facets of CustomerBased Brand Equity", Journal of Business Research, 57 (2), ss. 209-224.

Nunnally, J. C. ve Bernstein, I. H. (1994). Psychometric Theory (3rd ed.). New York: McGraw-Hill.

Oppermann, M. (2000), “Tourism Destination Loyalty”, Journal of Travel Research, 39, ss. 78-84.

Özoğul, T. ve Özel, Ç. H. (2015), "Destinasyonlara Yönelik Tüketici Temelli Marka Denkliği Algılarının Ölçümü: Eskişehir Örneği", Uluslararası Alanya Iş̧letme Fakültesi Dergisi, 7 (3), ss. 137-151. 
Pappu, R., Quester, P. ve Cooksey, R. W. (2005), "Consumer-Based Brand Equity: Improving The Measurement Empirical Evidence", Journal of Product \& Brand Management Emerald, 14 (3), ss. 143-154.

Petrick, J. F. (2004), "The Roles of Quality, Value, and Satisfaction in Predicting Cruise Passengers' Behavioural Intentions", Journal of Travel Research, 42, ss. 397407.

Phillips, W. J., Kara, W., Nancy H. ve Larry, L. F. (2013), "Tourist Word Of Mouth and Revisit Intentions to Rural Tourism Destinations: A Case of North Dakota, USA", International Journal of Tourism Research, 15(1), ss. 93-104.

Pike, S. ve Bianchi, C. (2013), "Destination Brand Equity for Australia: Testing A Model of CBBE in Short Haul and Long Haul Markets", Journal of Hospitality and Tourism Research, 20 (10), ss. 1-21.

Pike, S., Bianchi, C., Kerr, G. ve Patti, C. (2010), "Consumer-Based Brand Equity For Australia As a Long-Haul Tourism Destination in an Emerging Market", International Marketing Review, 27 (4), ss. 434-449.

Pratminingsih, A. S., Rudatin, L. C. ve Rimenta, T. (2014), "Roles of Motivation And Destination Image İn Predicting Tourist Revisit Intention: A Case Of BandungIndonesia", International Journal of Innovation, Management and Technology, 5 (1), $19-24$.

Scherer, R.F., Wiebe F.A., Luther, D.C. ve Adams, J.S. (1988), "Dimensionality Of Coping: Factor Stability Using The Ways of Coping Questionnaire". Psychological Reports, 62, ss. 763-770.

Sekaran, U. (2003), Research Methods for Business, John Wiley High Education Press: New York, ABD.

Shabbir, J., Rehman, K. U. (2013), "Impact of Perceptual Dimensions And Behavioral Dimentions On Brand Equity in Pakistan," Information Management and Business Review, 5(7), ss. 347-359.

Tabachnick, B. G. ve Fidell, L. S. (2013), Using Multivariate Statistics. (sixth ed.) Boston: Pearson.

Taşçı, A. D. A. ve Gartner, W. C. (2007), "Destination Image and Its Functional Relationships", Journal of Travel Research, 45 (4), ss. 413-425.

Tayfun, A. ve Yayla, Ö. (2013), "Turistlerin Otel Seçimlerinde Marka Sadakatini Etkileyen Faktörlerin Demografik Değişkenler Açısından İncelenmesi: Ankara örneği", İşletme Araştırmaları Dergisi, 5 (4), ss. 159-169.

Teas, R. K. ve Laczniak, R. N. (2004), "Measurement Process Context Effects in Empirical Tests of Causal Models", Journal of Business Research, 57 (2), ss. 162-174.

Townsend, P. ve Gebhardt, J. (1998), The Policy is Still Quality, Best's Review, June 1998.

Ural, T. ve Perk, H.G. (2012), "Tüketici Temelli Marka Değerinin Kişisel Bilgisayar Satın Alma Niyeti Üzerine Etkisi: Antakya'da Bir Çalışma," Anadolu Üniversitesi Sosyal Bilimler Dergisi, 12 (3), ss. 11-26.

Üner, M. Güçer, E. ve Taşçı, A. (2006), "Türkiye Turizminde Yükselen Destinasyon Olarak İstanbul Şehrinin İmajı," Anatolia: Turizm Araştırmaları Dergisi, 17 (2), ss. 189-201

Vinh, T. T. ve Nga, V.T.Q. (2015), "The Relationship Between Components of Customer-Based Brand Equity For Destination: Conceptual Framework And Preliminary Testing For Scales", South East Asia Journal of Contemporary Business, Economics and Law, 7 (2), ss. 47-53.

Yağmur, Y. ve Kolukısa, C. (2016), "Fransız Turistlerin Destinasyon Marka Değeri Deneyimleri: Kemer Yöresi Uygulaması”, Gümüşhane Üniversitesi Sosyal Bilimler Enstitüsü Dergisi, 7 (16), ss. 80-98. 
Yüksel, A. ve Yüksel F. (2004). Turizmde Bilimsel Araştırma Yöntemleri. Ankara: Turhan Kitapevi.

Yüksel, A., Yüksel, F. ve Bilim, Y. (2010), "Destination Attachment: Effects on Customer Satisfaction and Cognitive, Affective and Conative Loyalty", Tourism Management, 31 (2), ss. 274-284. 